\title{
LUGAR DE FALA NA ATIVIDADE JURISDICIONAL E O MITO DA INTERPRETAÇÃO AUTÊNTICA ${ }^{1}$
}

\section{PLACE OF SPEECH IN JUDICIAL ACTIVITY AND THE MITH OF THE AUTHENTIC INTERPRETATION}

Manoel Pedro Ribas de Lima Mestre pelo Programa de Pós-Graduação em Direito do UniBrasil. Especialista em Direito Processual Civil pela Universidade Estadual de Ponta Grossa (UEPG). Advogado. Ponta Grossa/PR. E-mail: manoel@ribasdelima.com.br.

Susana Maria Bartmeyer Bacharel em Direito e mestranda do Programa de PósGraduação em Ciências Sociais Aplicadas da Universidade Estadual de Ponta Grossa (UEPG). Ponta Grossa/PR. E-mail: smbartmeyer@hotmail.com.

RESUMO: Este artigo avalia a atividade jurisdicional através do lugar de fala. Se cabe às partes formular pretensões de suas posições na sociedade e, umas contra as outras, reivindicá-las, cabe ao julgador, superando tais perspectivas, atuar com neutralidade. Instrumento à mão deste está a norma, que, apesar de manipulável, identifica um âmbito semântico mínimo como resistência. O julgador, porém, também a pode ultrapassar graças à sua posição institucional privilegiada. Decisões judiciais recorrentes, que formam um conjunto jurisprudencial sólido, exemplificam o mau uso do lugar de fala. Interpretação autêntica figura como pretexto.

PALAVRAS-CHAVE: Decisão; Fundamentação; Atividade jurisdicional; Lugar de fala; Interpretação autêntica; Norma.

\footnotetext{
${ }^{1}$ Artigo recebido em 25/03/2021 e aprovado em 02/06/2021.
} 
ABSTRACT: This article evaluates judicial activity through the place of speech. If it is up to the parties to claim from their positions in society and, against each other, to plead them, it behooves to the judge, overcoming such perspectives, to act neutrally. An instrument at hand is the norm, which, although manipulable, identifies a minimal semantic scope as resistance. The judge, however, can also overcome it by his privileged institutional position. That supplement is exemplified by recurring court decisions, which form a solid jurisprudential set, and constitutes a misuse of the place of speech. Authentic interpretation arises as a trick.

KEYWORDS: Decision; Judicial activity; Place of speech; Authentic interpretation, Norm.

SUMÁRIO: 1. Introdução; 2. Lugar de fala: da reivindicação ao pretexto; 3. Uso ilegítimo do lugar de fala na decisão judicial; 4. Abordagem da análise do mau uso do lugar de fala; 5. Exemplo 1: liberação do devedor por quitação tácita em consignação extrajudicial; 6. Exemplo 2: mandado de segurança diante o esgotado prazo de vigência de certame sem a nomeação do candidato aprovado dentro do número de vagas ofertado; 7. Exemplo 3: nulidade de sentença dos embargos à execução fiscal na ausência de intimação específica para substituição de CDA; 8. A última palavra e o mito da interpretação autêntica; Referências.

\section{INTRODUÇÃO}

Parecerá intempestiva, senão ilegítima, qualquer crítica à estrutura judiciária vigente defronte o desmonte institucional pelo levante da desarrazoada e insolente extrema-direita que hoje ocupa a gestão governamental. É no Poder Judiciário que encontramos a salvaguarda para o discernimento e a resistência à barbárie. Todavia, isso não nos autoriza a fechar os olhos para os problemas que o próprio Judiciário enfrenta. A mesma crise do Estado Democrático de Direito que deu margem ao dissenso pseudo-ideológico é aquela que esgarça a atividade jurisdicional.

Por este trabalho ocupamo-nos do uso do lugar de fala, instrumento teorético em voga, para revelar, quanto trazida ela para a atividade jurisdicional, a dinâmica de pretextos 
no alicerce de decisões judiciais. Método e objeto se confundem neste texto. $\mathrm{O}$ destino inevitável destes esforços é a desmitificação da noção de interpretação autêntica: reserva-se ao órgão competente de aplicar o Direito dizer o que é o Direito. Miramos na descrição dessa ocorrência. Encontramos por ela fundamentações normativamente incongruentes e o medíocre encobrimento da indolência de membros do judiciário, o que direcionou nossos esforços para expô-las ativamente. Desnuda-se, na atividade jurisdicional, uma mecânica para a manutenção da concentração de força definidora do conteúdo normativo e de sua aplicação, com sua consequente mitigação de poder dentre os cidadãos e jurisdicionados.

Sequenciamos este texto em quatro sessões. O primeiro passo está na definição de lugar de fala e seu papel crítico. Apesar de receber litigantes individualizados de processo em processo, o magistrado atende a um auditório difuso e, em sua atividade, se sujeita à expectativa de comunicação generalizada. O segundo passo é a identificação negativa da norma como instrumento de comunicação jurisdicional, o que nos leva, na terceira etapa, a identificar usos falhos dessas ferramentas pela adesão às supostas interpretações institucionalmente idiossincráticas: a afirmação de normas que não atendem a interpretação geral dos respectivos enunciados. Por fim, confirma-se que esses posicionamentos circunscritos se sustentam pela própria estrutura do Poder Judiciário, como se, do seu lugar, a interpretação normativa bastaria a si, esvaziando substancialmente o fundamento da competência de proferi-los.

\section{LUGAR DE FALA: da reivindicação ao pretexto}

Lugar de fala corresponde à formulação afirmativa a partir de posições inseridas numa estrutura preexistente. Trata-se de um conceito recentemente consolidado, em especial pelos teóricos do pós-estruturalismo, mas que pode ser facilmente aliado às noções aristotélicas de topos e endoxa. Consideremos a organização social por um sistema estrutural. Seus integrantes estarão fixos em colocações discrepantes. Cada um deles restringir-se-á à finitude do horizonte de onde se situa. Toda mensagem proferida estará condicionada geograficamente e, de pronto, assim deve vir a ser filtrada. Qualquer emissão ordinária por um agente, sem conceber diretamente o campo de visão da localização alheia, firmará um ângulo conjuntural: o seu ângulo. É dessa comunicação prevaricar a visão dos 
outros. No diálogo, firmando-se em sua e da sua posição, surge um destino retórico a cada fala $^{2}$. Em termos vulgares, lugar de fala condiz à perspectiva e o intento decorrente dela.

Pretexto, como o concebemos, equivale a subterfúgio. Embora munido de papel retórico, ele não atende apenas à fundamentação de um posicionamento. Expliquemos. No viés puramente semântico, um pretexto configura-se no uso de argumentos falaciosos. Falase uma coisa e se faz outra. No sentido a ser trabalhado, a denominação do termo é expandida. O lugar de fala afigura-se como escape para a justificação. A instrumentalidade do pretexto não está só em ocultar os verdadeiros motivos do posicionamento, mas antes em usar do status do agente para acomodar um posicionamento. Decido assim porque assim é do meu ponto de vista.

Essa dupla explicação, embora simplista, já esboça nosso desenvolvimento. Se de um lado é legítimo o uso do lugar de fala por minorias para denunciar marginalizações, não se pode cogitar o mesmo deste uso na prestação judicial.

Toda comunicação pressupõe, por mais limitada que seja, uma pluralidade. Se há um lugar de fala, há um lugar de escuta. Um diz e outro o ouve. Trata-se de uma concepção que pressupõe diálogo ${ }^{3}$. Por mais limitados que sejam nossos horizontes e por mais que eles nos limitem, eles podem ser postos em xeque pelo que lhe é alienígena. Expõe-se, então, a discriminação sofrida a partir da ótica de quem a sofre para quem não a sofre, pois este, sem sofrê-la, não poderia dela sozinho se conscientizar. É tão importante falar quanto escutar. O lugar de fala favorece um em detrimento de outro. Não se trata apenas de falar, mas de falar para aqueles que normalmente não escutam. O papel do uso do lugar de fala deixa de ser, nessa comunicação, a de expor-se e reclamar, no sentido de lamentar ao fim de socorro. Aqueles que hegemonicamente tem a fala, na mesma intensidade, não praticam a escuta. Atribui-se ao lugar de fala o ato de vindicar, reclamar por reconhecimento para, sendo reconhecido, dialogar ${ }^{4}$.

Podem os brancos falar de antirracismo? Para Ribeiro, sim. Se o homem branco sempre falou, pouco praticou a escuta. Todos têm um lugar de fala. Cabe refletir sobre qual

\footnotetext{
${ }^{2}$ VIEHWEG, Theodor. Tópica e jurisprudência. Trad. Tércio Sampaio Ferraz Jr. Brasília: Departamento de Imprensa Nacional, 1979, p. 35.

${ }^{3}$ TIBURI, Marcia. Feminismo em comum: para todas, todes e todos. Rio de Janeiro; Rosa dos tempos, 2018.

${ }^{4}$ Há, obviamente, a instância econômico-social desse protesto, que é a de compensação, mas sua razão de ser reside na equidade e harmonia entre dignidades particulares. Ver BOSCO, Francisco. A vítima tem sempre razão?: Lutas identitárias e o novo espaço público brasileiro. São Paulo: Todavia, 2017, p. 84.
} 
é o local de fala que se ocupa e o porquê se ocupa. Propicia-se aos interlocutores a revisão da sua posição pela da do outro. Esse exercício é o reforço constante de que não há um sujeito universal que fala sobre todas as realidades a partir de todas elas. "O conceito de lugar de fala discute justamente o locus social, isto é, de que ponto as pessoas partem para pensar e existir no mundo, de acordo com as suas experiências em comum" 5 . Voltando à pergunta, se o racismo é um problema causado pelos brancos, é responsabilidade deles também a luta contra ele. Renunciado a idiossincrasia e o egoísmo, busca-se atingir o mais universalizável possível pela abertura do auditório à participação direta do maior número de pessoas. Busca-se ampliar sobremaneira a comunicação para dilatar o horizonte de cada interlocutor e a interação comunitária.

O magistrado está na comunidade numa posição privilegiada na estrutura políticoinstitucional. O poder de seu lugar repercute espontaneamente como força sobre os demais, compelidos estes à obediência. Publicamente falando, o magistrado jamais sofre, senão usufrui. De outro, dele há o compromisso com a neutralidade. Essa incumbência ética figurase na superação do seu lugar de fala para receber, acompanhado da devida crítica, o lugar da fala dos litigantes e dos demais cidadãos. Concebe-se e elogia-se o magistrado como alguém que, apesar de estar e se pronunciar a partir de um ponto particular, deve ultrapassar fronteiras e estruturas (eventualmente injustas) para se comunicar como toda a comunidade. É ele quem dá a última palavra no litígio, mas essa palavra não pode ser a dele, mas sim a da justiça.

Se cabe ao julgador o questionamento de sua posição e o que dessa posição ele recebe, não apenas a reverberar, então o uso de seu lugar de fala passa a ser-lhe totalmente ilegítimo. Dele resultaria, sobre os jurisdicionados, apenas dominação. Se não é concebível um universal, como pode um magistrado concretizar amplamente o justo? A maior comunicabilidade possível passa a ser-lhe critério de validade. Reclama-se a abertura do julgamento à crítica. Não é só propiciar à minoria à participação no Poder Judiciário, mantendo uma configuração de domínio, mas o abrir para o debate público.

Considerando o princípio dispositivo como caráter mais caro ao Judiciário (cujo oposto é o inquisitorial), essa abertura não acontece antes da decisão. As partes estão autorizadas a se valerem do seu lugar de fala exatamente porque calcados em pretensões. A

\footnotetext{
${ }^{5}$ RIBERIO, Djamila. Pequeno Manual Antirrascista. São Paulo: Companhia das Letras, 2019, p. 35.
} 
oportunidade reclamada precisa acontecer pela decisão. O magistrado precisa de ânimo e de mecanismos para ampliar a validade de seu julgamento ao maior número de pessoas.

Não há espaço, tempo, ou bagagem para debatermos e propormos neste artigo os mecanismos de abertura do posicionamento jurisdicional. Propor o contrário é, divertidamente, verdadeiro. Tendo em mãos os conceitos acima indicados, demonstraremos hipóteses do mau uso do lugar de fala pelos julgadores.

\section{USO ILEGÍTIMO DO LUGAR DE FALA NA DECISÃO JUDICIAL}

Para além de indiscrições entre advogados, já se constatou academicamente um perfil próprio à atuação do Poder Judiciário brasileiro: os posicionamentos tomados são opinativos aos magistrados que os proferem ${ }^{6}$. Nas decisões colegiadas, o dispositivo é definido pelo alinhamento das conclusões de cada membro da câmara ou turma (pela admissibilidade ou não do pedido, pela procedência ou não do mérito). Cada voto, em geral, apresenta uma fundamentação particular, não poucas vezes sem diálogo com os proferidos pelos pares. Embora isso possa alimentar o ego dos adeptos do realismo jurídico, isso não significa, imediatamente, a ausência de racionalidade das decisões, tampouco sua incomunicabilidade. Ainda resiste um instrumento institucional patente de intercurso e, de modo subjacente, de abertura do magistrado em sua decisão: a norma (seja por enunciados legais ou jurisprudenciais).

Como a norma pode nos servir de critério para a análise da abertura do magistrado em sua decisão? Se adotássemos o modelo do juiz Hércules de Dworkin, espera-se do julgador, ao menos, a integração normativa adequada. Não sejamos inocentes. As normas, por suas possibilidades semânticas (as zonas cinzentas de Hart), proporcionam ao magistrado o manejo delas de forma relativamente arbitrária. Neste trabalho nos apropriaremos da tese da filosofia analítica ${ }^{7}$. Pode-se usar uma chave-inglesa tanto para apertar roscas, seu desígnio supostamente precípuo, como, graças a ser ela uma peça maciça,

\footnotetext{
${ }^{6}$ RODRIGUEZ, José Rodrigo. Como decidem as cortes?: para uma crítica do direito (brasileiro). FGV: São Paulo, 2013, p. 69.

${ }^{7}$ AUSTIN, Jonh L. A Plea for Excuses: The Presidential Address. In Proceedings of the Aristotelian Society, vol. 57, 1956, pp. 1-30. Oxford: Oxford University Press. Disponível em JSTOR, www.jstor.org/stable/4544570 $\quad$ e $\quad$ em https://edisciplinas.usp.br/pluginfile.php/4121800/mod_resource/content/1/AustinPlea56.pdf, com acesso neste último em 02/12/2020.
} 
comprida e pesada, para pregar, marretar, amassar, macerar, alavancar, mexer, ou, simplesmente, como enfeite. De igual modo, enunciados legais podem ser aplicados a substratos fáticos inimagináveis ao legislador, como, para hipóteses inicialmente restritas, serem trazidas diferentes incidências. $O$ registro da união homoafetiva como casamento foi alcançada, por exemplo, independentemente de alterações legais (ADI 4277 e ADPF 132). A norma está à mão do julgador. Conceitos são cunhados e readequados cotidianamente. Diante dessa instrumentalidade, passa a ser falso acreditar que fundamentação normativa imprime um motivo normativo, como polemizou Engish contra Isay ${ }^{8}$. Também passa a ser fidedigna, em contrapartida, a alegação de Goodhart de que se pode extrair bons posicionamentos de uma fundamentação ruim ${ }^{9}$.

Isso nos faz concordar, para os mais familiarizados à predominante apropriação de Alexy pelos nacionais, com Humberto Ávila, ao firmar que regras, e não só princípios, são passíveis de ponderação ${ }^{10}$. Do resultado dele nos apartamos, contudo, quando admitimos serem hipócritas e ressentidos os mais ricos em argumentos. Calma! A norma não se coloca como critério positivo de validade da decisão, mas sim negativo. Foi Weber quem primeiro esboçou este entendimento ${ }^{11}$. Assim como a materialidade da ferramenta, as palavras possuem uma contenção ao uso. A chave-inglesa nunca irá prestar para cortar. Pelo seu formato, ela não tem fio. Quanto às palavras, suas possibilidades de uso, salvo nas ironias e sarcasmos, estão balizadas por acepções particulares. Todo uso da palavra, por mais criativo que seja, esbarra no inverso do que dela se quer dizer. O não pagamento, por exemplo, não implica necessariamente o devedor em mora, mas jamais pode autorizá-lo a se liberar unilateralmente da obrigação. Embora o sucessor possa usufruir da herança desde a abertura da sucessão, sua possibilidade de disposição fica limitada até a partilha.

Equívocos normativos patentes acontecem, mas são raros, posto que pouquíssimas normas possuem âmbito de incidência exclusivo. Quando acontecem, suas fundamentações são facilmente alteradas. Também há normas inválidas, que merecem ser manifestamente

\footnotetext{
${ }^{8}$ ENGISH, Karl. Introdução ao pensamento jurídico. $11^{\mathrm{a}}$ ed. Trad. João Baptista Machado. Lisboa: Fundação Calouste Gulbenkian, 2014, p. 84-85.

${ }_{9}^{9}$ GOODHART, Arthur L. Determining the racio decidendi of a case; in The Yale Law Journal. Vol. 40. N. 2. Dez. 1930, p. 165. Disponível em: http://www.umiacs.umd.edu/ horty/courses/readings/goodhart-1930ratio.pdf. Acesso em 05/12/2017.

${ }^{10}$ ÁVILA, Humberto. Teoria dos Princípios: da definição à aplicação dos princípios jurídicos. $11^{\mathrm{a}}$ ed. São Paulo; Malheiros, 2010, p. 63.

${ }^{11}$ WEBER, Max. O direito na economia e na sociedade. São Paulo: Ícone, 2011, p. 83
} 
sobrepujadas. Normalmente diferentes normas concorrem, direta e indiretamente, sobre um mesmo evento. Com efeito, o mais comum é nos depararmos com processos integrativos, o que elimina a possibilidade do ostensivo mau uso do lugar da fala. A moldura interpretativa suposta por Kelsen $^{12}$, que já estava esgarçada pelas possibilidades matemáticas do emprego estático dos enunciados, agora são alavancadas pela integração. Todavia, com as alterações dinâmicas de entendimentos ao longo do tempo, seja porque advindas de revogações e promulgações legais, seja por teses jurisprudenciais e mutações constitucionais, passa-se a evidenciar fundamentações legalmente incoerentes, revelando o mau uso tanto dos precedentes quanto o uso ilegítimo do lugar de fala.

A seguir reunimos, longe de temas polêmicos, exemplos corriqueiros e, por meio deles, aprofundaremos na dinâmica do dito mau uso.

\section{ABORDAGEM DA ANÁLISE DO MAU USO DO LUGAR DE FALA}

Algumas advertências antes de prosseguir.

Primeiro, não está em pauta eventual culpa de juízes. É mais apropriado crer, pela dialeticidade e pelos inúmeros processos (não por e para cada litígio em particular), numa mútua influência entre os diferentes atores institucionais. Advogados, os primeiros julgadores do litígio, buscam antecipar as decisões dos magistrados pelo histórico destes, como estes daqueles acabam apreendendo alternativas de posicionamento (em especial nos litígios atípicos). Pelos registros e pela publicidade das decisões, os magistrados apenas estão mais expostos.

Segundo, não cabe realizar uma estatística sobre a postura dos magistrados. Há carência de dados. Embora possamos colecionar decisões dos tribunais (cujos meios oficiais parecem piores ao longo dos últimos anos), não há plataforma acessível de pesquisa de decisões de primeira instância. E não é autorizado supor que contra toda sentença haja recurso, tampouco que, quanto haja, todos sejam conhecidos pelo juízo ad quem. Ainda, não é adequado supor uma distribuição, tanto quanto um desvio, normal das causas decisórias.

12 KELSEN, Hans. Teoria Pura do Direito. Trad. João Baptista Machado. $6^{a}$ ed. São Pualo: Martins Fontes, 1998, p. 388. 
Cada magistrado é um, possui sua personalidade e seu cotidiano, sendo impossível um cálculo de resultados do fortuito (isso sem contar com sua liberdade).

Esta análise, obviamente post factum, legitima-se por não ser mecânica, mas por ser jurígena. Nas fundamentações deparamo-nos com absurdos racionais e desvios do ponderável - injustas ao papel público dos tribunais, não necessariamente à cada um dos litígios que foram julgados.

\section{EXEMPLO 1: liberação do devedor por quitação tácita em consignação extrajudicial}

Diferentes Tribunais de Justiça sustentam, baseados no $§ 2^{\circ}$ do art. 539 do Código de Processo Civil, a liberação integral do devedor à obrigação cuja consignação bancária a título de pagamento foi levantamento sem ressalvas pelo credor ${ }^{13}$. Imaginemos um condômino, por exemplo, insatisfeito com a administração do edifício. Ele, reticente ou de má-fé, consigna em banco oficial valor inferior ao correspondente ao resultado do rateio dos custos de manutenção das áreas comuns. Ao invés de cem ele deposita cinquenta. O síndico, diante da premência e recorrência das despesas, o que não lhe assegura tempo hábil para designar uma assembleia ao fim de obter autorização do uso do fundo de reserva, levanta os valores consignados. Pelo entendimento acima, o simples levantamento, sem qualquer ressalva, retira desse condomínio a possibilidade de exigir em juízo daquele condômino o valor faltante. Sobre essa diferença haveria quitação tácita.

O Código Civil vigente, replicando o texto do diploma anterior, condiciona, em seu art. 336, a força de pagamento da consignação à concorrência de todos os elementos constitutivos da obrigação. O valor está entre eles. Nenhum credor é obrigado a receber prestação diversa da devida (C. Civil, art. 313). Acresce-se a esse raciocínio a inexistência

\footnotetext{
13 Neste sentido: TJSP - Apelação Cível 1120461-82.2017.8.26.0100; Relator (a): Fabio Tabosa; Órgão Julgador: 29a Câmara de Direito Privado; Foro Central Cível - 42 ${ }^{\mathrm{a}}$ Vara Cível; Data do Julgamento: 26/08/2020; Data de Registro: 27/08/2020; TJPR - 8 C.Cível - 0002615-46.2017.8.16.0001 - Curitiba - Rel.: Juiz Alexandre Barbosa Fabiani - J. 06.04.2020; TJMG - Apelação Cível 1.0702.16.027051-9/001, Relator(a): Des.(a) José Américo Martins da Costa, $15^{\text {a }}$ CÂMARA CÍVEL, julgamento em 29/08/2019, publicação da súmula em 04/09/2019; TJBA - Classe: Apelação, Número do Processo: 0521765-93.2016.8.05.0001, Relator(a): MARCIA BORGES FARIA, Publicado em: 19/03/2019; TJDF - Acórdão 1145073, 07107112420188070001, Relator: ANA CANTARINO, $8^{\mathrm{a}}$ Turma Cível, data de julgamento: 12/12/2018, publicado no DJE: 22/1/2019. Pág.: Sem Página Cadastrada; TJRJ, Apelação Civil 000080352.2011.8.19.0079 - Relator Custódio de Barros Tostes, Julgamento em 30/05/2017; entre outros. Todas estas decisões foram colhidas em 04/12/2020.
} 
de quitação presumida (C. Civil, art. 319) e da vedação de interpretação extensiva aos atos liberatórios (C. Civil, art. 114). Na ausência de um valor integral, não há que se falar de pagamento integral. A leitura globalizada entre estes dispositivos só pode gerar um entendimento: liberação proporcional à parcela consignada e levantada.

O dispositivo do Código de Processo Civil citado enuncia que, passados dez dias do recebimento do aviso da consignação pelo credor sem a recusa deste, "considerar-se-á o devedor liberado da obrigação". Essa redação, que replica a do código anterior (revogado em 2015), nada diz sobre a extensão do pagamento, tampouco levantamento sem ressalva na hipótese de pagamento parcial. Não se pode negar que uma tradição pelo entendimento da liberação integral, como antes exposto, o antecede. Sustentá-lo, contudo, supõe existir uma antinomia deste dispositivo contra os do Código Civil: enquanto a norma do diploma material libera o devedor na proporção do valor pago, a do processual, do qual não necessariamente se nega caráter material, liberaria na integralidade da obrigação.

Supondo que exista uma antinomia, ela não se resolve por si. O choque entre enunciados abre um vácuo lógico. Os sentidos deles, como linhas paralelas, jamais se conciliam exceto por um terceiro elemento, que, vindo de fora para dentro, venha a servir de critério para estabelecer âmbitos de validade distintos (como, por exemplo, a especificidade dos enunciados sobre a questão - LICC, art. $2^{\circ}, \S 2^{\circ}$-, ou ainda a distinção entre âmbitos de incidência).

Todas as decisões encontradas, cuja última nota de rodapé arrola apenas algumas posteriores a 2017, falam de ressalva ou não do credor à consignação; resistência que, num esforço comissivo do leitor, pressupõe-se como critério. Pressupõe-se porque a objeção seria, segundo as fundamentações prestadas, um elemento exclusivo do $\S 2^{\circ}$ do art. 539 do Código de Processo Civil ao falar de recusa, não um terceiro elemento.

Se houvesse antinomia, qual o porquê de preferir o art. 539 do Código de Processo Civil ao 336 do Código Civil? Sem um critério racional externo que dirigisse essas decisões para uma ou para outra norma, os magistrados deixaram de fundamentar nestas decisões o porquê o dispositivo processual se sobreporia ao material. O iuri novit curia não afasta o dever de fundamentação. Pelo contrário. A fundamentação faz-se condição de validade da decisão $\left(\mathrm{CPC}, \operatorname{art.} 489, \S 1^{\circ}\right)$. 
As coisas ficam piores quando se depara com o tema repetitivo 967 do Superior Tribunal de Justiça ${ }^{14}$, o qual firma a liberação proporcional, não integral, na hipótese de depósito parcial em ação consignatória. Quando confrontados com este precedente, os magistrados daquelas decisões firmaram apenas que a ação de cobrança do valor faltante não atendia o respectivo âmbito fático. O art. 539 do Código de Processo Civil por eles usado volta-se especificamente à ação consignatória.

O dispositivo processual não possui texto distinto do material, o que, além da integração do ordenamento, confirma um sentido comum entre eles. A suposta antinomia não existe. Aliás, já em 2017 o Superior Tribunal de Justiça, pelo AgInt no AREsp 731.852/DF, aplicou o esse entendimento em ação de cobrança, admitindo a exigência da parcela não depositada. Por que os Tribunais de Justiça persistem no entendimento anterior?

\section{EXEMPLO 2: mandado de segurança diante o esgotado prazo de vigência de certame sem a nomeação do candidato aprovado dentro do número de vagas ofertado}

Através do Recurso Extraordinário n ${ }^{\circ} 598.099$ de relatoria do Ministro Gilmar Mendes, de 10 de agosto de 2011, o Supremo Tribunal Federal consolidou o entendimento de haver ao candidato aprovado no número de vagas ofertadas em concurso público o direito subjetivo à nomeação ao cargo para o qual concorreu (decisão arrolada como Tema 161). A validade do edital está condicionada à previsão orçamentária (Constituição da República, art. $169, \S 1^{\circ}$, I e II). Não pode haver convocação de aprovado em concurso posterior enquanto houver candidatos aprovados pelo anterior (Lei $\mathrm{n}^{\circ} 8.112 / 1990$, art. 12, $\S 2^{\circ}$ ). Os candidatos depositam confiança na Administração que convoca o concurso. Portanto, o edital, que para o concurso se faz lei, vincula tanto o particular que aí se inscreve quanto a entidade da Administração Pública que o promove.

Essa mesma decisão, ao firmar que a Administração Pública não pode dispor da nomeação, reconheceu a disponibilidade do tempo da nomeação. Há que se atribuir para todo certame um tempo de vigência, conforme o caput do art. 12 da Lei $n^{\circ}$ 8.112. Esse

\footnotetext{
${ }^{14}$ Em ação consignatória, a insuficiência do depósito realizado pelo devedor conduz ao julgamento de improcedência do pedido, pois o pagamento parcial da dívida não extingue o vínculo obrigacional. Publicado em 23/10/2018. Disponível em: https://processo.stj.jus.br/repetitivos/temas_repetitivos/pesquisa.jsp?novaConsulta=true\&tipo_pesquisa=T\&s g_classe $=$ REsp\&num_processo_classe $=1108058$. Acesso em 05/12/2020.
} 
tempo, conforme este enunciado, é de dois anos prorrogáveis uma vez por igual período. Entenderam os ministros do Supremo, então, caber à Administração definir nesse lapso o momento da nomeação.

Embora essa decisão pareça sustentável prima facie, já que sobre o direito à nomeação a vigência do certame poderia figurar como prazo para o dever da Administração Pública, condição suspensiva ao candidato aprovado, tal solução não se pode sustentar em termos maiores. $\mathrm{O}$ direito à nomeação vincula-se intrinsecamente ao certame; a vigência deste corresponde ao daquele. Essa incoerência normativa desponta de forma patente com a resposta processual para quando esse prazo se esgota sem a nomeação: cabimento de mandado de segurança em cento e vinte dias contados do termo final da vigência do certame $^{15}$.

Encontram-se precedentes no Superior Tribunal de Justiça, ainda quando controverso o tempo da nomeação, tomando o mandado de segurança como medida cabível para assegurar a nomeação. A exemplo da decisão do Recurso em Mandado de Segurança ${ }^{\circ}$ 10877/MG, de relatoria do Ministro Hamilton Carvalhido e datada de 06 de fevereiro de 2003, entendia-se que o prazo para impetrar o mencionado writ era contado da homologação do resultado do concurso. Tratando-se de ato vinculado, não haveria que se falar do lapso de vigência do certame e no seu transcurso. Pois bem! Diante da decisão do Supremo antes citada, da qual já era possível falar de eficácia vertical diante de uma interpretação extensiva do parágrafo único do art. 28 da Lei nº 9.868/1.999 (efeito vinculante a todo judiciário pelas decisões do controle de constitucionalidade), rearranjou-se o termo inicial do mandado de segurança.

A inconsistência aqui reside na correlação entre a condição do certame para o direito à nomeação e o requisito ao mandado de segurança. De um lado, a vigência do certame representa, para o direito à nomeação, prazo decadencial. Há direito à nomeação enquanto vigente o prazo do certame. Passado esse prazo, esse direito se extingue porque, extinto o certame, deixa de haver a oferta de vaga. De outro, mandado de segurança só tem seu mérito

\footnotetext{
${ }^{15}$ Neste sentido, exclusivamente o Superior Tribunal de Justiça: REsp 1784318/SP, Rel. Ministro HERMAN BENJAMIN, SEGUNDA TURMA, julgado em 07/05/2019, DJe 12/09/2019; AgInt no RMS 58.405/SP, Rel. Ministro SÉRGIO KUKINA, PRIMEIRA TURMA, julgado em 19/03/2019, DJe 22/03/2019; AgInt no REsp 1417814/SC, Rel. Ministro GURGEL DE FARIA, PRIMEIRA TURMA, julgado em 11/09/2018, DJe 08/10/2018; AgInt no REsp 1705049/RO, Rel. Ministra ASSUSETE MAGALHÃES, SEGUNDA TURMA, julgado em 15/03/2018, DJe 22/03/2018; RMS 55.464/RJ, Rel. Ministro MAURO CAMPBELL MARQUES, SEGUNDA TURMA, julgado em 21/11/2017, DJe 27/11/2017; entre outros.
} 
conhecido quanto reclamado tutela de direito líquido e certo (Constituição da República, art. 5, LXIX, e Lei $\mathrm{n}^{\circ}$ 12.016/2009, art. $1^{\circ}$ ). Pelas designações de liquidez e certeza ao direito subjetivo foca-se primariamente na capacidade de comprovação probatória imediata, dispensando outros meios que não documental (a chamada dilação probatória). Isto, contudo, é o produto do direito, enquanto incidência. Direito é um elemento normativo, portanto faticamente potencial. Quando se fala em certeza, independentemente de sua simplicidade ou complexidade abstrata, esse direito precisa ser, primeiro, normativamente existente ${ }^{16}$. Então, se considerado o termo inicial do prazo para impetrar o mandado de segurança o termo final da vigência do certame, estar-se-á tutelando direito incerto porque extinto.

$\mathrm{O}$ art. 12 da Lei 8.112 não correlaciona prazo do certame a prazo para nomeação. Se não fosse pela decisão do Supremo, entender-se-ia que o prazo indicado é para a realização do certame, de seu edital de convocação até o edital de nomeação (daí a razão do posicionamento anterior pelo Superior Tribunal de Justiça). Que premissa normativa o Supremo teve em mãos, se não sua própria posição, para o novo entendimento?

\section{EXEMPLO 3: nulidade de sentença dos embargos à execução fiscal na ausência de intimação específica para substituição de $\operatorname{CDA}^{17}$}

Como apanágio do tradicional interesse público, a Lei n ${ }^{\circ} 6.830 / 1980$, em seu art. $2^{\circ}$, $\S 8^{\circ}$, o Código Tributário Nacional, em seu art. 203, e a Súmula 392 do Superior Tribunal de Justiça reconhecem válida a substituição ou emenda da certidão de dívida ativa, que serve de título executivo às ações de execuções fiscais, caso ela esteja maculada por vícios materiais ou formais (desde que mantido o sujeito passivo). Ambos os enunciados prescrevem que esta substituição deve acontecer até o esgotamento da primeira instância, assegurando a devolução de prazo de embargos ao executado.

\footnotetext{
${ }^{16}$ Valendo-nos de exemplo bem simples, é certo falar do direito à indenização por dano moral por inscrição indevida em cadastro de proteção ao crédito, mas não é líquido, porque dependente de prova da inscrição e de sua invalidade. Não é certo um direito normativamente dúbio, que não conta com prévio enunciado legal ou jurisprudencial. Não falamos de sua complexidade, admitido sim pelo writ, mas de sua concretude. A permanência de criança recebida por família a margem de processo de adoção, por exemplo, contraria regra, mas tutelável perante o princípio do melhor interesse em jogo. Esse interesse precisa ser analisado in loco, o que, conseguintemente, demanda tanto dilação probatória quanto o exame de ponderação. Perde-se a certeza prima facie.

${ }^{17}$ Agradecemos a Mozart Cercal da Silva pela indicação deste exemplo.
} 
Inobstante a possibilidade de substituição mencionada (excetuando-se o art. 141 do Código de Processo Civil), o seu limite processual, como indicado, corresponde processualmente ao fato superveniente. $\mathrm{O}$ magistrado deve levar em conta todo e qualquer fato posterior ao ajuizamento da ação capaz de influir em julgamento (CPC, art. 493), implicando no dever de consideração do estado das coisas no momento da entrega da prestação jurisdicional. Pode-se falar que, encerrada a instrução, toda alegação de fato estaria definitivamente preclusa (CPC, art. 366 c/c 223). Passado o julgamento, novas alegações desta seara, caracterizando inovação recursal, são manifestamente vedadas (CPC, 1.014), implicando na sua inadmissão.

Reforçando a proteção do interesse público, o Superior Tribunal de Justiça, através do Agravo Regimental em Recurso Especial n 1268359/PE, firmou que não se pode extinguir a execução fiscal face nulidade da certidão de dívida ativa sem antes intimar a Fazenda Pública para a emenda ou substituição do título. Apesar de esta posição não conter inconsistência normativa patente, ela foi motivo para uma: declarações de nulidade de sentenças de embargos de declaração julgados procedentes em primeira instância, nulidade esta decorrente da ausência de prévia intimação para possível substituição da certidão de dívida ativa. Neste outro sentido são encontradas decisões nos Tribunais de Justiça de São Paulo $^{18}$, de Pernambuco ${ }^{19}$, do Mato Grosso do $\mathrm{Sul}^{20}$ e do Rio Grande do Sul ${ }^{21}$.

É hilário ver que, caso os embargos se voltem contra a validade da certidão de dívida ativa, a Fazenda Pública, ao ser citada para defender-se, fica automaticamente intimada sobre a possibilidade do vício, facultando-se a ela a substituição ou não na execução fiscal. Sim, essa substituição subsequente implica na perda de objeto dos embargos com a condenação da Fazenda frente ao princípio da causalidade. Não houve, contudo, a prática de um vício? O processo é estruturado no contraditório, o qual significa a possibilidade de qualquer posição, desde a defesa, o reconhecimento do pedido até a preclusão lógica por ato

\footnotetext{
18 TJSP; Apelação Cível 1001327-05.2019.8.26.0581; Relator (a): Eurípedes Faim; Órgão Julgador: 15ª Câmara de Direito Público; Foro de São Manuel - $2^{\mathrm{a}}$ Vara; Data do Julgamento: 09/11/2020; Data de Registro: 09/11/2020.

${ }^{19}$ Apelação Cível 290218-30017203-10.2009.8.17.0810, Rel. Luiz Carlos de Barros Figueirêdo, $3{ }^{\text {a }}$ Câmara de Direito Público, julgado em 13/02/2014, DJe 19/02/2014.

${ }^{20}$ TJMS. Apelação Cível n. 0801314-11.2019.8.12.0021, Três Lagoas, 4ª Câmara Cível, Relator (a): Des. Luiz Tadeu Barbosa Silva, j: 24/07/2020, p: 29/07/2020.

${ }^{21}$ Apelação Cível, N ${ }^{\circ} 70048450225$, Segunda Câmara Cível, Tribunal de Justiça do RS, Relator: Sandra Brisolara Medeiros, Julgado em: 23-04-2012
} 
satisfatório da pretensão do autor. Propiciou-se a substituição ou emenda da certidão de dívida ativa ao longo de toda a tramitação dos embargos e a Fazenda Pública declinou dessa chance. Defender a validade da certidão viciada só torna mais absurda a situação, pois patenteia a resistência à pretensão do embargante/executado que tem razão. Que racionalidade existe numa sentença de primeira instância em julgar improcedente os embargos na omissão da Fazenda Pública? Ou de um acórdão em anular a procedência dos embargos?

\section{A ÚLTIMA PALAVRA E O MITO DA INTERPRETAÇÃO AUTÊNTICA}

Uma incongruência normativa constituiu nada mais que uma falha lógica. Considerando a antecedência do arcabouço legal e jurisprudência à decisão, a incoerência, mesmo que não se evidencie internamente, repercute externamente. Nenhum teste racionável pode recepcioná-la.

Em todas as hipóteses arroladas houve questionamento contra o respectivo argumento. Por que persistir com ele? A resposta está no lugar de fala do magistrado dentro da configuração institucional do Estado. Iura novit curia. O julgador, em manifesto ato de vontade, cria direito ao definir a solução do caso concreto. E, uma vez publicada, essa decisão repercute como manifestação do próprio Tribunal. Não nos valemos de decisões isoladas. Vimos que uma mesma posição, inobstante sua irracionalidade formal, repete-se pelos tribunais em inúmeros casos. Nesse entendimento reiterado falar-se-ia de interpretação autêntica.

Quando Kelsen propôs a interpretação autêntica ele manifestamente assumiu a precedência dos juízes aos cidadãos. Fatores históricos o explicam. Parecia-lhe suficientemente válida a crença na "ética da responsabilidade" baseada numa legitimidade racionalista, onde a ordem legal espelharia um espectro objetivo. Isso lhe representava imparcialidade, pois o ato de vontade do magistrado seria precedido por um fato cognitivo. Isso foi posteriormente aterrado pela permanência da estrutura constitucional, ao menos em termos judiciários, nos regimes totalitaristas ${ }^{22}$.

\footnotetext{
${ }^{22}$ ARENDT, Hannah. Origens do totalitarismo. Trad. Roberto Raposo. São Paulo: Companhia das letras, 2004, p. 444.
} 
Tribunais de Justiça e Regionais repetem indistintamente decisões do Supremo e do Superior Tribunais de Justiça acriticamente. Desembargadores e juízes de segundo grau, posto nossas fontes residirem principalmente nos tribunais, acabam por socorrer retoricamente decisões dos magistrados de primeira instância sem prejuízo ao posicionamento. Nelas preteriram a integridade racional do Tribunal em prol da concentração do seu poder. Ao recusar-se em responder pelo porquê da escolha, os magistrados caem em petição de princípio (o velho "porque sim"). Com sua recursividade, retira-se a dignidade de falas externas, o que só se sustenta pela soberba da posição institucional $^{23}$.

Ainda que assumíssemos a concepção contraintuitiva de correspondência entre interpretação e aplicação (a qual cautelosamente procuramos não irritar neste texto), devemos nos perguntar o que autorizaria a sobreposição da interpretação dos tribunais sobre a dos demais agentes jurídicos e políticos. O texto, embora passível à relatividade de interpretações diversas, não persiste, em relação aos seus leitores, e se reifica? Não é o magistrado mais um intérprete entre tantos outros dentro da comunidade? Não é aos jurisdicionados que as normas se aplicam e, somente quando resistidas pretensões entre eles, que o judiciário é acionado?

Para que não haja equívocos ao leitor. Não defendemos aqui o direito positivo. Os formalistas acusam a justiça como irredutível ${ }^{24}$ ao mesmo tempo em que se agarram à forma por entendê-la como justa. E o problema da ponderação e da abertura das normas não é a ponderação, mas o uso dela para "erigir-se em tirano único de todo o ethos humano, ao custo de outros valores, inclusive dos que não lhe sejam, do ponto de vista material, diametralmente opostos" ${ }^{25}$. Se precisamos explicar o que os magistrados fazem que não interpretação, devemos deixar de defender uma ética da legalidade para defendemos uma ética.

O lugar de fala dos magistrados destaca-se das falas dos demais operadores do Direito por ser a última na cadeia de manifestações até a definição da sanção. Nada nela pressupõe

\footnotetext{
${ }^{23}$ RANCIÈRE, Jacques. $O$ desentendimento: política e filosofia. Trad. Ângela Leite Lopes. $2^{\mathrm{a}}$ Ed. São Paulo: Editora 34, 2018, p. 32. Aí esse autor cita Aristóteles, Política, I. 1254 b 22: “o escravo é aquele que participa da comunidade da linguagem apenas sob a forma de compreensão [aisthesis], não da posse [hexis].

${ }^{24}$ GRAU, Eros Roberto. Por que tenho medo de juízes: a interpretação/aplicação do direito e os princípios. $9^{\mathrm{a}}$ ed. São Paulo: Malheiros, 2018, p. 22.

${ }^{25}$ Ibid., p. 26.
} 
superioridade qualitativa. $\mathrm{O}$ magistrado não legitima sua decisão por ocupar um posto institucional de julgador. Pelo contrário: isso o deixa na berlinda. Nada mais horrendo que privilégios sem contrapartida. Para representar o justo, o magistrado precisa deixar de representar a si. A norma, seja regra, seja princípio, é-lhe apenas instrumento, não fim. A integração normativa até pode ser de livre apreciação do magistrado (no sentido de liberação a qualquer condicionamento), o posicionamento tomado não.

Ao denunciarmos a petição de princípio em temas corriqueiros padecemos de uma decepção adicional. Nossos exemplos não refletem um maquiavelismo, no seu sentido pejorativo, sem esquecer que carecem de criatividade e sofisticação, distintivo da hipocrisia. Por eles não foi exercido qualquer espécie de controle de constitucionalidade. Sua recursividade desata de uma situação concreta. Mesmo numa perspectiva geral, não há nenhuma vantagem a médio ou longo prazo nas posições assumidas.

Calamandrei firma que, em seu tempo, a maior corrupção dos magistrados não é serem eles corruptos, mas indolentes ${ }^{26}$. Sua caricatura dos magistrados como sedentários corresponde exatamente o mau uso do lugar de fala que estes podem fazer. Não dizemos que os Tribunais devem se deixar levar pelas massas. Passa a ser-lhe vedado, contudo, apenas agir com concupiscência, firmando entendimentos indiferentemente ao litígio e ao mundo em que este se insere. O magistrado é, antes de sua incumbência, um cidadão e, como tal, dele se espera uma interação ostensiva com os demais. Ele deve se defrontar com a comunidade que integra.

\section{REFERÊNCIAS:}

ARENDT, Hannah. Origens do totalitarismo. Trad. Roberto Raposo. São Paulo: Companhia das letras, 2004.

AUSTIN, Jonh L. A Plea for Excuses: The Presidential Address. In Proceedings of the Aristotelian Society, vol. 57, 1956, pp. 1-30. Oxford: Oxford University Press. Disponível em JSTOR, www.jstor.org/stable/4544570 e em

\footnotetext{
${ }^{26}$ CALAMANDREI, Piero. Eles, os juízes, vistos por um advogado. Trad. Eduardo Brandão. 2. Ed. São Paulo: WMF Martins Fontes, 2015, p. 117.
} 
https://edisciplinas.usp.br/pluginfile.php/4121800/mod_resource/content/1/AustinPl ea56.pdf.

ÁVILA, Humberto. Teoria dos Princípios: da definição à aplicação dos princípios jurídicos. $11^{\mathrm{a}}$ ed. São Paulo; Malheiros, 2010.

BOSCO, Francisco. A vítima tem sempre razão?: Lutas identitárias e o novo espaço público brasileiro. São Paulo: Todavia, 2017.

CALAMANDREI, Piero. Eles, os juízes, vistos por um advogado. Trad. Eduardo Brandão. 2. Ed. São Paulo: WMF Martins Fontes, 2015.

ENGISH, Karl. Introdução ao pensamento jurídico. Trad. João Baptista Machado. $11^{\mathrm{a}}$ ed. Lisboa: Fundação Calouste Gulbenkian, 2014.

GOODHART, Arthur L. Determining the racio decidendi of a case; in The Yale Law Journal. Vol. 40. N. 2. Dez. 1930, p. 165. Disponível em: http://www.umiacs.umd.edu/ horty/courses/readings/goodhart-1930-ratio.pdf.

GRAU, Eros Roberto. Por que tenho medo de juízes: a interpretação/aplicação do direito e os princípios. $9^{a}$ ed. São Paulo: Malheiros, 2018.

KELSEN, Hans. Teoria Pura do Direito. Trad. João Baptista Machado. $6^{\text {a }}$ ed. São Pualo: Martins Fontes, 1998.

RANCIÈRE, Jacques. $O$ desentendimento: política e filosofia. Trad. Ângela Leite Lopes. $2^{\mathrm{a}}$ Ed. São Paulo: Editora 34, 2018.

RIBERIO, Djamila. Pequeno Manual Antirrascista. São Paulo: Companhia das Letras, 2019.

RODRIGUEZ, José Rodrigo. Como decidem as cortes?: para uma crítica do direito (brasileiro). FGV: São Paulo, 2013.

TIBURI, Marcia. Feminismo em comum: para todas, todes e todos. Rio de Janeiro; Rosa dos tempos, 2018.

VIEHWEG, Theodor. Tópica e jurisprudência. Trad. Tércio Sampaio Ferraz Jr. Brasília: Departamento de Imprensa Nacional, 1979.

WEBER, Max. O direito na economia e na sociedade. São Paulo: Ícone, 2011 